\title{
Keterampilan Berpikir Kritis Siswa pada Konsep Mekanika di SMA Negeri 5 Palu
}

\author{
Risnawati, Marungkil Pasaribu dan Syamsu \\ risnawatinana@ymail.com \\ Program Studi Pendidikan Fisika FKIP Universitas Tadulako \\ Jl. Soekarno Hatta Km. 9 Kampus Bumi Tadulako Tondo Palu - Sulawesi Tengah
}

Penelitian ini bertujuan untuk mendeskripsikan seberapa besar tingkat keterampilan berpikir kritis siswa pada konsep mekanika pada materi gerak. Subjek penelitian ini adalah siswa kelas XI IPA 1 SMA Negeri 5 Palu yang terdiri dari 40 siswa. Data diperoleh melalui lembar jawaban tes keterampilan berpikir kritis siswa dan wawancara. Pemberian tes keterampilan berpikir kritis terdiri atas 10 soal essay untuk menentukan enam responden dengan skor tertinggi, sedang dan rendah yang bertujuan dapat memperoleh data untuk mencakupi keragaman kemampuan yang dimiliki siswa serta dapat menentukan siswa dalam menentukan saat proses wawancara berlangsung. Hasil penelitian menunjukkan bahwa keterampilan berpikir kritis siswa pada konsep mekanika yang dibatasi pada materi gerak berada pada kategori sedang. 3 subjek dikategorikan sangat kritis, 24 subjek kritis dan 13 subjek kurang kritis. Hal ini diperoleh dari 10 sub-indikator keterampilan berpikir kritis yaitu memfokuskan pertanyaan dengan skor 58.5, menganalisi argumen dengan skor 65 , bertanya dan menjawab pertanyaan dengan skor 82.5, mempertimbangkan apakah sumber dapat dipercaya atau tidak dengan skor 64.5, mengobservasi dan mempertimbangkan hasil observasi dengan skor 23.5, mendeduksi dan mempertimbangkan hasil deduksi dengan skor 19, menginduksi dan mempertimbangkan hasil induksi dengan skor 66, membuat dan menentukan hasil pertimbangan dengan skor 55, mendefenisikan istilah dan mempertimbangkan suatu defenisi dengan skor 83.5 dan mengidentifikasi asumsi-asumsi dengan skor 73.5.

Kata Kunci : keterampilan berpikir kritis, konsep mekanika

\section{PENDAHULUAN}

Ilmu Pengetahuan Alam (IPA) berkaitan dengan cara mencari tahu tentang gejala alam secara sistematis, sehingga IPA bukan hanya penguasaan kumpulan pengetahuan yang berupa fakta-fakta, konsep-konsep, atau prinsip-prinsip saja tetapi juga merupakan suatu proses penemuan. Fisika merupakan salah satu cabang IPA yang menjelaskan mengapa dan bagaimana proses-proses fenomena alam terjadi.

Halpen (1996), menyatakan bahwa kritis adalah memperdayakan keterampilan atau strategi kognitif dalam menentukan tujuan [1]. Pendapat serupa disampaikan oleh [2], menyatakan bahwa berpikir kritis adalah mengaplikasikan rasional, kegiatan berpikir yang tinggi, yang meliputi kegiatan menganalisis, mensintesis, mengenal permasalahan dan pemecahannya, menyimpulkan, dan mengevaluasi [2]. berpikir kritis adalah cara berpikir reflektif yang masuk akal atau berdasarkan nalar yang difokuskan untuk menentukan apa yang harus diyakini dan dilakukan[3].

kadang orang awam bahkan guru masih terkagum-kagum dengan banyaknya informasi yang bisa diungkap seseorang[4]. Seperti telah disampaikan di atas bahwa berpikir kritis merupakan bagian penting dari aspek kehidupan seseorang, termasuk siswa.

Oleh karena itu harus ada perubahan paradigma mengajar dari hanya memberikan informasi menjadi mengajarkan cara mencari informasi dan mempergunakannya untuk halhal lain yang bermanfaat. Pendidikan berpikir di sekolah saat ini khususnya di SMA belum di tangani dengan baik. Guru hanya berupaya meningkatkan kemampuan kognitif siswa. Akibatnya kecakapan berpikir lulusan SMA masih relatif rendah. Penelitian yang telah dilakukan, mengemukakan bahwa terjadi keluhan tentang rendahnya keterampilan berpikir kritis-kreatif lulusan dasar sampai perguruan tinggi di Indonesia, karena pendidikan berpikir belum ditangani dengan baik[5].

Keterampilan berpikir suatu keterampilan yang dapat dipelajari dan diajarkan karena berpikir kritis merupakan sebuah proses yang terarah dan jelas yang digunakan dalam kegiatan mental seperti memecahkan masalah, mengambil keputusan, membujuk, menganalisis asumsi dan melakukan penelitian ilmiah.

Melalui penjelasan di atas, maka diperoleh gambaran bahwa keterampilan berpikir kritis yang dimiliki siswa tingkat 
Sekolah Menengah Atas (SMA) masih sangat kurang. Kecendrungan ini sering terbawa hingga ke tingkat perguruan tinggi. Seorang guru harus mampu menuntun para siswa untuk meningkatkan keterampilan berpikir kritis dengan memberikan informasi dan mengajarkan siswa cara mencari informasi.

Dari masalah yang di ungkapkan maka penelitian ini bertujuan untuk mengetahui seberapa besar tingkat keterampilan berpikir kritis siswa pada konsep mekanika.

\section{METODE PENELITIAN}

Penelitian ini menggunakan pendekatan deskriptif-kualitatif yang datanya berupa faktafakta yang ada. Subjek dalam penelitian ini adalah 40 siswa kelas XI IPA 1 SMA Negeri 5 Palu bulan Januari Tahun Ajaran 2015/2016. Responden dalam penelitian ini sebanyak 6 (enam) orang siswa berdasarkan tingkat keterampilan siswa yang dibagi menjadi 3 kategori yaitu tinggi, sedang dan rendah. Responden dipilih berdasarkan nilai tes yang diperoleh yakni 2 siswa dengan nilai tertinggi, 2 siswa dengan nilai sedang dan 2 siswa dengan nilai terendah.

Pemilihan ke-enam responden dengan skor tertinggi, sedang dan terendah ini bertujuan dapat memperoleh data untuk mecakupi keragaman kemampuan yang dimiliki siswa serta dapat menentukan siswa dalam menentukan saat proses wawancara berlangsung.

Adapun Instrumen yang digunakan pada penelitian ini berupa tes keterampilan berpikir kritis yang disesuaikan dengan indikator yang digunakan oleh peneliti dalam bentuk soal-soal uraian sebanyak 10 nomor.

Tehnik analisa data yang digunakan: Tehnik analisis data kualitatif yang dilakukan selama dan setelah pengumpulan data, dengan tahap-tahap mereduksi data, menyajikan data, dan penarikan kesimpulan dan verifikasi.

Tehnik wawancara yang digunakan adalah wawancara kualitatif artinya mengajukan pertanyaan-pertanyaan secara lebih bebas dan leluasa tanpa terikat oleh suatu susunan pertanyaan yang telah dipersiapkan sebelumnya. Pendekatan interpretative dilakukan pada saat proses wawancara, pendekatan ini salah satu cara dalam menggali dan mengungkapkan data dan informasi melalui wawancara kualitatif.

\section{HASIL DAN PEMBAHASAN}

Penelitian ini menggunakan tes keterampilan berpikir kritis sebanyak 10 nomor serta divalidasi oleh dosen pembimbing dan dosen lain sebagai validator ahli. Hasil validitas dan validator ahli terhadap instrumen penelitian: Parameter yang di ukur adalah penggunaan bahasa, kesesuaian dengan indikator, kejelasan makna, kesesuaian isi, rasionalitas tes dan kebenaran konsep. Dengan skor tiap aspeknya adalah (1) kualitas dari aspek tersebut kurang, (2) kualitas dari aspek tersebut cukup, (3) kualitas dari aspek tersebut baik, dan (4) kualitas dari aspek tersebut sangat baik.

Hasil pengelolaan data, skor rata-rata yang diperoleh adalah 58,85 dan nilai standar deviasi adalah 17,59. Berdasarkan skor ratarata dan standar deviasi tersebut, responden yang terpilih untuk tes wawancara berdasarkan kategori disajikan pada Tabel 1.

Tabel 1. Kode dan Kategori Responden

\begin{tabular}{ccc}
\hline No & $\begin{array}{c}\text { Inisial } \\
\text { Responden }\end{array}$ & Kategori \\
\hline 1 & R-01 & Tinggi \\
\hline 2 & R-02 & Tinggi \\
\hline 3 & R-12 & Sedang \\
\hline 4 & R-13 & Sedang \\
\hline 5 & R-28 & Rendah \\
\hline 6 & R-40 & Rendah \\
\hline
\end{tabular}

Responden yang telah terpilih diwawancarai secara bergantian untuk mengkonfirmasi jawaban siswa dari hasil tes keterampilan berpikir kritis yang telah siswa jawab sebelumnya.

Secara ringkas, seluruh ringkasan hasil wawancara kepada keenam responden ditabulasi ke dalam Tabel 2.

Tabel 2. Tabulasi Hasil Wawancara

\begin{tabular}{|c|c|c|c|c|c|c|}
\hline \multirow{2}{*}{$\begin{array}{l}\text { Masalah yang } \\
\text { diungkap }\end{array}$} & \multicolumn{6}{|c|}{ Responden } \\
\hline & R-01 & R-02 & R-12 & R-13 & R-28 & R-40 \\
\hline $\begin{array}{l}\text { Kurang } \\
\text { memahami materi } \\
\text { (Konsep, } \\
\text { Persamaan) }\end{array}$ & & & $\checkmark$ & $\checkmark$ & $\checkmark$ & $\checkmark$ \\
\hline Minim persiapan & & & & & $\checkmark$ & $\checkmark$ \\
\hline $\begin{array}{l}\text { Kurangnya } \\
\text { kemampuan } \\
\text { matematis }\end{array}$ & & & & $\checkmark$ & $\checkmark$ & $\checkmark$ \\
\hline $\begin{array}{l}\text { Kesulitan } \\
\text { menganalisis } \\
\text { kata-kata }\end{array}$ & & & & & & $\checkmark$ \\
\hline $\begin{array}{l}\text { Kurang } \\
\text { MampuMemilih } \\
\text { Persamaan }\end{array}$ & & & $\checkmark$ & & & $\checkmark$ \\
\hline Ketidaktelitian & $\checkmark$ & $\checkmark$ & $\checkmark$ & $\checkmark$ & $\checkmark$ & $\checkmark$ \\
\hline Berd & rkan & tab & & sil & awan & ara \\
\hline ;esuai Tab & 2 & terlił & & hwa & terd & pat \\
\hline
\end{tabular}


beberapa faktor yang menyebabkan rendahnya keterampilan sebagian besar responden penelitian dalam mengerjakan tes yang diberikan. Adapun faktor yang paling sering dikemukakan oleh responden adalah kurang ketelitian dalam mengerjakan soal.

Berdasarkan analisa data hasil pekerjaan dan wawancara siswa tentang keterampilan berpikir kritis, diperoleh hasil untuk setiap subindikator yang disajikan berikut:

\section{Memfokuskan Pertanyaan}

Pada soal pertama sub-indikator memfokuskan pertanyaan, besarnya skor yang diperoleh subjek penelitian sebesar 58,5. Nilai ini merupakan nilai urutan keempat terendah dari 10 sub-indikator keterampilan berpikir kritis yang diteskan. Pada sub-indikator memfokuskan pertanyaan subjek penelitian diminta untuk menyelesaikan soal:

$>$ Perhatikan grafik di bawah ini!

Grafik hubungan kecepatan terhadap waktu

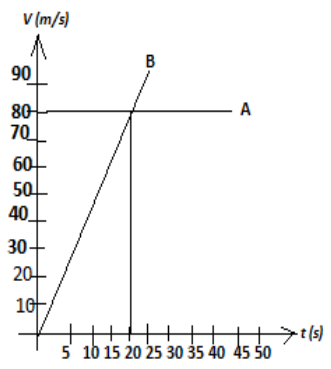

Grafik diatas adalah grafik hubungan kecepatan terhadap waktu dari dua buah mobil A dan B.

a. Jelaskan jenis gerak dari mobil A dan B!

b. Pada jarak berapakah mobil A dan B akan bertemu?

R-01 menyatakan bahwa responden paham tentang konsep jenis gerak, namun tidak pada saat mencari jarak kedua mobil pada saat bertemu dikarenakan kurangnya ketelitian saat menjawab. R-02 menyatakan bahwa bahwa responden paham tentang konsep jenis gerak, namun tidak pada saat mencari jarak kedua mobil pada saat bertemu dikarenakan kurangnya ketelitian responden pada saat menentukan persamaan yang digunakan dalam penyelesaikan soal.

R-12 menyatakan bahwa responden paham tentang konsep jenis gerak, namun responden kurang memahami materi (persamaan) pada saat mencari jarak kedua mobil pada saat bertemu dikarenakan kurang mampu memilih persamaan. R-13 menyatakan bahwa responden paham tentang konsep jenis gerak, namun responden kurang ketelitian terhadap persamaan serta kurangnya kemampuan matematis saat menyelesaikan masalah.

R-28 menyatakan bahwa responden belum paham tentang konsep jenis gerak dan mencari jarak. Ini dikarenakan responden kurang memahami materi (konsep, persamaan), kurangnya kemampuan matematis, kesulitan menganalisis kata-kata, serta ketidaktelitian. R-40 menyatakan bahwa responden belum paham tentang konsep jenis gerak dan mencari jarak. Ini dikarenakan responden kurang memahami materi (konsep, persamaan), kurangnya kemampuan matematis, kesulitan menganalisis kata-kata, kurang mampu memilih persamaan, serta ketidaktelitian dan minim persiapan dalam menyelesaikan masalah.

\section{Menganalisis Argumen}

Pada soal kedua sub-indikator menganalisis argumen, besarnya skor yang diperoleh subjek penelitian sebesar 65 . Nilai ini merupakan nilai urutan kelima dari 10 subindikator keterampilan berpikir kritis yang diteskan. Pada sub-indikator menganalisis argumen subjek penelitian diminta untuk menyelesaikan soal:

$>$ Perhatikan pernyataan dibawah ini!

a. Sebuah mobil mula-mula bergerak dengan kecepatan $5 \mathrm{~m} / \mathrm{s}$. dalam selang waktu 5 sekon kecepatannya berubah menjadi $25 \mathrm{~m} / \mathrm{s}$. Maka mobil tersebut telah mengalami percepatan.

b. Nana pergi ke Lambunu dari palu bersama Ihsan dengan mengendarai motor. Saat dari palu ke Lambunu Ihsan melihat speedometer menunjukan angka $70 \mathrm{~km} / \mathrm{jam}$ kemudian Ihsan dan Nana kembali lagi dari Lambunu ke Palu dengan angka pada speedometer $70 \mathrm{~km} / \mathrm{jam}$. Dari fenomena ini dan terlihat pada speedometer bahwa kelajuan motor adalah $70 \mathrm{~km} / \mathrm{jam}$ dan kecepatannya pun $70 \mathrm{~km} / \mathrm{jam}$.

Apakah pernyataan tentang kelajuan dan kecepatan diatas benar? Jelaskan!

R-01 menyatakan bahwa responden paham tentang konsep kelajuan dan kecepatan. R-02 menyatakan bahwa responden paham tentang konsep kelajuan dan kecepatan.

R-12 menyatakan bahwa responden kurang dalam memahami konsep sehingga menyebabkan responden kesulitan menganalisis kata-kata serta ketidaktelitian. R13 menyatakan bahwa responden kurang memahami materi (konsep, persamaan) dan ketidaktelitian. 
R-28 menyatakan bahwa responden tidak memahami konsep kelajuan dan kecepatan dikarenakan responden kurang memahami materi (konsep, persamaan), kurangnya kemampuan matematis, kesulitan menganalisis kata-kata, serta ketidaktelitian dan minim persiapan dalam menyelesaikan masalah. R-40 menyatakan menyatakan bahwa responden tidak memahami konsep kelajuan dan kecepatan dikarenakan responden kurang memahami materi (konsep, persamaan), kurangnya kemampuan matematis, kesulitan menganalisis kata-kata, kurang mampu memilih persamaan, serta ketidaktelitian dan minim persiapan dalam menyelesaikan masalah.

\section{Bertanya dan Menjawab Pertanyaan}

Pada soal ketiga sub-indikator bertanya dan menjawab pertanyaan, besarnya skor yang diperoleh subjek penelitian sebesar 82,5 . Nilai ini merupakan nilai tertinggi urutan kedua dari 10 sub-indikator keterampilan berpikir kritis yang diteskan. Pada sub-indikator bertanya dan menjawab pertanyaan subjek penelitian diminta untuk menyelesaikan soal:

> Sebutkan 3 contoh gerak lurus beraturan (GLB) dan gerak lurus berubah beraturan (GLBB) dalam kehidupan sehari-hari yang anda ketahui!

R-01 menyatakan bahwa responden paham tentang menyebutkan contoh gerak lurus beratutan dan berubah beraturan. R-02 menyatakan bahwa responden paham tentang menyebutkan contoh gerak lurus berubah beraturan.

R-12 menyatakan bahwa responden paham tentang contoh gerak lurus berubah beraturan. R-13 hanya mengikuti jawaban teman sebangkunya ini disebabkan kurang persiapan dalam menyelesaikan masalah yang diberikan.

R-28 menyatakan bahwa responden kurang paham konsep gerak lurus beraturan dan gerak lurus berubah beraturan, ini disebabkan kurang memahami materi (konsep, persamaan), kurangnya kemampuan matematis, kesulitan menganalisis kata-kata, serta ketidaktelitian. R-40 menyatakan bahwa responden tidak memahami konsep kelajuan dan kecepatan dikarenakan responden kurang memahami materi (konsep, persamaan), kurangnya kemampuan matematis, kesulitan menganalisis kata-kata, kurang mampu memilih persamaan, serta ketidaktelitian dan minim persiapan dalam menyelesaikan masalah.
4. Mempertimbangkan Apakah Sumber Dapat di Percaya atau Tidak

Pada soal keempat sub-indikator mempertimbangkan apakah sumber dapat dipercaya atau tidak, besarnya skor yang diperoleh subjek penelitian sebesar 64,5 . Nilai ini merupakan nilai urutan keenam dari 10 subindikator keterampilan berpikir kritis yang diteskan. Pada sub-indikator mempertimbangkan apakah sumber dapat dipercaya atau tidak, subjek penelitian diminta untuk menyelesaikan soal:

> Indah mengayuh sepedanya ke timur dengan kecepatan konstan $4 \mathrm{~m} / \mathrm{s}$ selama 20 detik lalu membelok ke utara dengan kecepatan konstan $3 \mathrm{~m} / \mathrm{s}$ selarna 15 detik. Sedangkan Ana mengayuh sepedanya ke utara dengan kecepatan konstan $3 \mathrm{~m} / \mathrm{s}$ selama 20 detik lalu membelok ke timur dengan kecepatan konstan $4 \mathrm{~m} / \mathrm{s}$ selama 20 detik. Apakah jarak yang diternpuh Indah lebih jauh dari pada jarak yang ditempuh Ana? Jelaskan!

R-01 menyatakan bahwa responden paham mengenai konsep perbedaan jarak dan perpindahan. R-02 menyatakan bahwa responden paham mengenai konsep perbedaan jarak dan perpindahan.

R-12 menyatakan bahwa responden kurang paham dalam konsep perbedaan antara jarak dan perpindahan dikarenakan responden kurang memahami materi (konsep). R-13 menyatakan bahwa responden kurang paham dalam konsep perbedaan antara jarak dan perpindahan dikarenakan responden kurang memahami materi (konsep).

R-28 menyatakan bahwa responden kurang paham konsep gerak lurus beraturan dan gerak lurus berubah beraturan, ini disebabkan kurang memahami materi (konsep, persamaan), kurangnya kemampuan matematis, kesulitan menganalisis kata-kata, serta ketidaktelitian. R-40 menyatakan bahwa responden tidak memahami konsep kelajuan dan kecepatan dikarenakan responden kurang memahami materi (konsep, persamaan), kurangnya kemampuan matematis, kesulitan menganalisis kata-kata, kurang mampu memilih persamaan, serta ketidaktelitian dan minim persiapan dalam menyelesaikan masalah.

5. Mengobservasi dan Mempertimbangkan Hasil Observasi

Pada soal kelima sub-indikator mengobservasi dan mempertimbangkan laporan 
observasi, besarnya skor yang diperoleh subjek penelitian sebesar 23,5. Nilai ini merupakan urutan nilai kedua terendah dari 10 subindikator keterampilan berpikir kritis yang diteskan. Pada sub-indikator mengobservasi dan mempertimbangkan laporan observasi, subjek penelitian diminta untuk menyelesaikan soal:

> Randi memegang bola di atas gedung dengan ketinggian 20 meter dan melemparkan horizontal ke depan dengan kecepatan awal $5 \mathrm{~m} / \mathrm{s}$. Ikbal yang berada di bawah gedung berjalan searah lemparan bola. Pada jarak berapa bola yang dilempar Randi mengenai Ikbal?

R-01 menyatakan bahwa responden mengerti tentang mencari jarak bola, namun responden kurang ketelitian saat menjawab sehingga menyebabkan responden hanya terfokus pada soal sebelumnya yang responden dapatkan dan mengerjakan sesuai apa yang terisirat dipikirannya. R-02 menyatakan bahwa responden mengerti tentang mencari jarak bola, namun responden kurang ketelitian saat menjawab sehingga menyebabkan responden hanya terfokus pada soal sebelumnya yang responden dapatkan dan mengerjakan sesuai apa yang diketahuinya.

R-12 menyatakan bahwa responden tidak paham tentang konsep parabola, ini disebabkan kurangnya responden dalam memahami materi, kurangnya dalam kemampuan matematis, serta ketidaktelitian dan minim persiapan. R-13 menyatakan bahwa responden tidak paham tentang konsep parabola dikarenakan kurangnya memahami materi, kurangnya kemampuan matematis, dan kurangnya ketelitian.

R-28 menyatakan bahwa responden kurang paham konsep gerak lurus beraturan dan gerak lurus berubah beraturan, ini disebabkan kurang memahami materi (konsep, persamaan), kurangnya kemampuan matematis, kesulitan menganalisis kata-kata, serta ketidaktelitian. R-40 menyatakan bahwa responden tidak memahami konsep kelajuan dan kecepatan dikarenakan responden kurang memahami materi (konsep, persamaan), kurangnya kemampuan matematis, kesulitan menganalisis kata-kata, kurang mampu memilih persamaan, serta ketidaktelitian dan minim persiapan dalam menyelesaikan masalah.

\section{Mendeduksi dan Mempertimbangkan Hasil} Deduksi
Pada soal keenam sub-indikator mendeduksi dan mempertimbangkan hasil deduksi, besarnya skor yang diperoleh subjek penelitian sebesar 19. Nilai ini merupakan nilai yang paling terendah dari 10 sub-indikator keterampilan berpikir kritis yang diteskan. Pada sub-indikator mendeduksi dan mempertimbangkan hasil deduksi, subjek penelitian diminta untuk menyelesaikan soal:

$>$ Rudi mengendarai mobil dari arah Palu pada pukul 08.00 pagi menuju Donggala yang berjarak $30 \mathrm{~km}$ dengan kecepatan konstan $40 \mathrm{~m} / \mathrm{s}$. pada saat perjalanan rudi berhenti di kedai untuk minum kopi, setelah itu rudi melanjutkan perjalanannya kembali selama 20 menit dan berhenti kembali untuk pengisian bensin. Rudi melanjutkan kembali perjalanannya selama 30 menit dan berhenti untuk beristirahat dirumah makan. Dari rumah makan Rudi melanjutkan perjalanannya hingga tiba di Donggala. Pada pukul berapa Rudi sampai di Donggala ?

R-01 menyatakan bahwa responden tidak paham tentang soal cerita mengenai perjalanan Rudi ke Donggala, ini disebabkan kurangnya ketelitian dan kurangnya reponden memilih persamaan yang digunakan. R-02 menyatakan bahwa responden tidak paham tentang soal cerita mengenai perjalanan Rudi ke Donggala, ini disebabkan kurangnya ketelitian dan kurangnya reponden memilih persamaan yang digunakan.

R-12 menyatakan bahwa responden tidak paham tentang soal cerita menganai perjalanan Rudi ke Donggala, ini disebabkan kurangnya memahami materi (konsep, persamaan), kurangnya kemampuan matematis, kurang mampu memilih persamaan, serta ketidaktelitian dan minim persiapan dalam menyelesaikan masalah. R-13 menyatakan bahwa responden tidak paham tentang soal cerita menganai perjalanan Rudi ke Donggala, ini disebabkan kurangnya memahami materi (konsep, persamaan), kurangnya kemampuan matematis, kesulitan menganalisis kata-kata, kurang mampu memilih persamaan, serta ketidaktelitian dan minim persiapan dalam menyelesaikan masalah.

R-28 menyatakan bahwa responden kurang paham konsep gerak lurus beraturan dan gerak lurus berubah beraturan, ini disebabkan kurang memahami materi (konsep, persamaan), kurangnya kemampuan matematis, kesulitan menganalisis kata-kata, serta ketidaktelitian. R-40 menyatakan bahwa responden tidak memahami konsep kelajuan 
dan kecepatan dikarenakan responden kurang memahami materi (konsep, persamaan), kurangnya kemampuan matematis, kesulitan menganalisis kata-kata, kurang mampu memilih persamaan, serta ketidaktelitian dan minim persiapan dalam menyelesaikan masalah.

7. Menginduksi dan Mempertimbangkan Hasil Induksi

Pada soal ketujuh sub-indikator menginduksi dan mempertimbangkan hasil induksi, besarnya skor yang diperoleh subjek penelitian sebesar 66. Nilai ini merupakan urutan nilai keempat dari 10 sub-indikator keterampilan berpikir kritis yang diteskan. Pada sub-indikator menginduksi dan mempertimbangkan hasil induksi, subjek penelitian diminta untuk menyelesaikan soal:

$>$ Anda bersama teman-teman anda pergi berlibur di Tanjung Karang Donggala dengan naik bus. Teman yang duduk dibelakang sopir selama 5 menit mengamati bahwa spedometer bus selalu tetap pada angka $60 \mathrm{~km} / \mathrm{jam}$. Ia kemudian mengatakan bahwa selama 5 menit bus tersebut tidak mengalami percepatan. Teman lain menanggapi bahwa selama 5 menit bus tersebut mengalami pecepatan tetapi percepatannya tetap. Apakah anda setuju dengan salah satu pendapat teman anda, atau anda memiliki pendapat sendiri? Jelaskan!

R-01 menyatakan bahwa responden memahami konsep percepatan. R-02 menyatakan bahwa responden memahami konsep percepatan. R-12 menyatakan bahwa respoden paham tentang konsep percepatan. $\mathrm{R}$ 13 menyatakan bahwa responden paham tentang konsep percepatan. R-28 menyatakan bahwa responden kurang paham konsep gerak lurus beraturan dan gerak lurus berubah beraturan, ini disebabkan kurang memahami materi (konsep, persamaan), kurangnya kemampuan matematis, kesulitan menganalisis kata-kata, serta ketidaktelitian. R-40 menyatakan bahwa responden tidak memahami konsep kelajuan dan kecepatan dikarenakan responden kurang memahami materi (konsep, persamaan), kurangnya kemampuan matematis, kesulitan menganalisis kata-kata, kurang mampu memilih persamaan, serta ketidaktelitian dan minim persiapan dalam menyelesaikan masalah.

8. Membuat dan Menentukan Hasil
Pada soal kedelapan sub-indikator membuat dan menentukan hasil pertimbangan, besarnya skor yang diperoleh subjek penelitian sebesar 55. Nilai ini merupakan urutan nilai ketiga terendah dari 10 sub-indikator keterampilan berpikir kritis yang diteskan. Pada sub-indikator membuat dan menentukan hasil pertimbangan, subjek penelitian diminta untuk menyelesaikan soal:

> Sebuah bola ditendang ke udara sehingga lintasannya berbentuk parabola. Bila kecepatan awal bola $30 \mathrm{~m} / \mathrm{s}$ dan sudut elevasinya $30^{\circ}$. Berapakah :

a. ketinggian maksimum serta waktu yang diperlukan untuk mencapai ketinggian dan

b. jarak jangkauan serat waktu yang diperlukan untuk mencapai jarak tersebut.

R-01 menyatakan bahwa responden paham tentang konsep gerak parabola, namun responden mengaku tidak yakin atas jawabannya ini disebabkan kurangnya ketelitian responden. R-02 menyatakan bahwa responden kurang teliti dalam menyelesaikan soal yang diberikan. R-12 menyatakan bahwa responden paham, namun responden mengaku tidak mengingat rumusnya hal ini disebabkan responden kurangnya kemampuan matematis dan kurang mampu memilih persamaan. R-13 menyatakan bahwa responden kurang paham dikarenakan kurangnya ketelitian dan kurang memahami konsep materi maupun persamaan.

R-28 menyatakan bahwa responden kurang paham konsep gerak lurus beraturan dan gerak lurus berubah beraturan, ini disebabkan kurang memahami materi (konsep, persamaan), kurangnya kemampuan matematis, kesulitan menganalisis kata-kata, serta ketidaktelitian. R-40 menyatakan bahwa responden tidak memahami konsep kelajuan dan kecepatan dikarenakan responden kurang memahami materi (konsep, persamaan), kurangnya kemampuan matematis, kesulitan menganalisis kata-kata, kurang mampu memilih persamaan, serta ketidaktelitian dan minim persiapan dalam menyelesaikan masalah.

9. Mendefenisikan Istilah dan
Mempertimbangkan Suatu Defenisi
Pada soal kesembilan sub-indikator mendefenisikan istilah dan mempertimbangkan suatu defenisi, besarnya skor yang diperoleh subjek penelitian sebesar 83,5. Nilai ini merupakan nilai tertinggi dari 10 sub-indikator keterampilan berpikir kritis yang diteskan. Pada 
sub-indikator mendefenisikan istilah dan mempertimbangkan suatu defenisi, subjek penelitian diminta untuk menyelesaikan soal:

$>$ Jelaskan menurut anda apa yang dimaksud dengan kecepatan sesaat dan kecepatan rata-rata?

R-01 menyatakan bahwa responden memahami konsep kecepatan sesaat dan keceptan rata-rata. R-02 menyatakan bahwa responden paham mengenai konsep kecepatan sesaat dan kecepatan rata-rata. R-12 menyatakan bahwa responden paham tentang konsep kecepatan sesaat dan kecepatan ratarata. R-13 menyatakan bahwa responden paham tentang konsep kecepatan sesaat dan kecepatan rata-rata.

R-28 menyatakan bahwa responden kurang paham konsep gerak lurus beraturan dan gerak lurus berubah beraturan, ini disebabkan kurang memahami materi (konsep, persamaan), kurangnya kemampuan matematis, kesulitan menganalisis kata-kata, serta ketidaktelitian. R-40 menyatakan bahwa responden tidak memahami konsep kelajuan dan kecepatan dikarenakan responden kurang memahami materi (konsep, persamaan), kurangnya kemampuan matematis, kesulitan menganalisis kata-kata, kurang mampu memilih persamaan, serta ketidaktelitian dan minim persiapan dalam menyelesaikan masalah.

\section{Mengidentifikasi Asumsi-asumsi}

Pada soal kesepuluh sub-indikator mengidentifikasi asumsi-asumsi, besarnya skor yang diperoleh subjek penelitian sebesar 73,5. Nilai ini merupakan nilai tertinggi urutan ketiga dari 10 sub-indikator keterampilan berpikir kritis yang diteskan. Pada sub-indikator mengidentifikasi asumsi-asumsi, subjek penelitian diminta untuk menyelesaikan soal:

> Berdasarkan gambar grafik di bawah benda manakah yang bergerak dengan cepat, apakah benda I atau II? Jelaskan menurut jawaban anda!

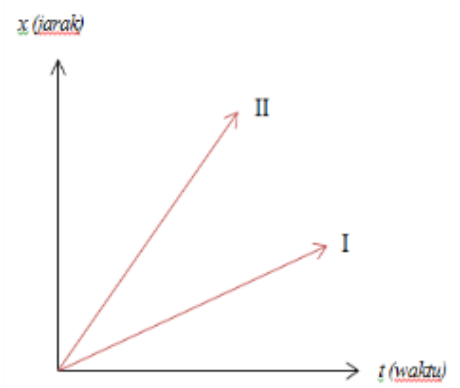

R-01 menyatakan bahwa responden benar saat menjawab gambar II namun alasan menjawab responden belum pasti ini disebabkan kurangnya ketelitian dalam menjawab. R-02 menyatakan bahwa responden benar saat menjawab gambar II namun alasan menjawab responden belum pasti ini disebabkan kurangnya ketelitian dalam menjawab. R-12 menyatakan bahwa responden belum paham tentang alasan yang digunakan dalam memilih jawaban sehingga menyebabkan responden kesulitan dalam menganalisis katakata. R-13 menyatakan bahwa responden belum paham tentang alasan yang digunakan dalam memilih jawaban sehingga menyebabkan responden kesulitan dalam menganalisis katakata.

R-28 menyatakan bahwa responden kurang paham konsep gerak lurus beraturan dan gerak lurus berubah beraturan, ini disebabkan kurang memahami materi (konsep, persamaan), kurangnya kemampuan matematis, kesulitan menganalisis kata-kata, serta ketidaktelitian. R-40 menyatakan bahwa responden tidak memahami konsep kelajuan dan kecepatan dikarenakan responden kurang memahami materi (konsep, persamaan), kurangnya kemampuan matematis, kesulitan menganalisis kata-kata, kurang mampu memilih persamaan, serta ketidaktelitian dan minim persiapan dalam menyelesaikan masalah.

\section{KESIMPULAN}

Hasil penelitian menunjukan bahwa keterampilan berpikir kritis siswa pada konsep mekanika yang dibatasi pada materi gerak berada pada kategori sedang. Dimana sebanyak 24 subjek kritis, 13 subjek kurang kritis dan 3 subjek sangat kritis. Dengan hasil:

a. Keterampilan siswa dalam memfokuskan pertanyaan masih kurang.

b. Keterampilan siswa dalam menganalisis argumen masih kurang.

c. Keterampilan siswa dalam bertanya dan menjawab pertanyaan sangat baik.

d. Keterampilan siswa dalam mempertimbangkan apakah sumber dapat dipercaya atau tidak masih kurang.

e. Keterampilan siswa dalam mengobservasi dan mempertimbangkan hasil observasi masih sangat kurang.

f. Keterampilan siswa dalam mendeduksi dan mempertimbangkan hasil deduksi masih sangat kurang. 
g. Keterampilan siswa dalam menginduksi dan mempertimbangkan hasil induksi masih kurang.

h. Keterampilan siswa dalam membuat dan menentukan hasil pertimbangan masih kurang.

i. Keterampilan siswa dalam mendefenisikan istilah dan mempertimbangkan suatu defenisi sangat baik.

j. Keterampilan siswa dalam mengidentifikasi asumsi-asumsi masih kurang.

\section{DAFTAR PUSTAKA}

[1] Halpen, D.F. (1996). Thinking Critically Abaut Critical Thinking: An Exercise Book to Accompany Thought and Knowledge: An Introduction to Critical Thinking (3 rd ed.). Mahwah, NJ: Lawrence Erlbaum Associates, Inc. Publishers.

[2] Angelo, T.A. (1995). Beginning the dialogue: Thoughts on promoting critical thinking: Classroom assessment for critical thinking. Teaching of Psychology, 22(1), 6-7.

[3] Ennis, H.R. (1985). The Critical Thinking Skills. Boston: Allyn \& Bacon.

[4] Wibowo, S. (2010). Dilema Mengajarkan Isi atau Cara Berpikir. [Online]. Tersedia:

http://agung1971.wordpress.com/2010/ 03/29/dilema-mengajar-isi-atau-caraberpikir/ [23 januari 2015].

[5] Rofiudin. (2000). "Rendahnya Keterampilan Berpikir Kritis". Jurnal pendidikan Indonesia fisika Indonesia. 8 (2000): 57-60

[6] Anri, Yohanes. (2013). Analisis Kemampuan Pemecahan Masalah Mahasiswa Calon Guru Pada Materi Mekanika. Jurnal Pendidikan Fisika Tadulako. 1 (2)

[7] Tunnisa, Taskirah. (2015). Kemampuan Pemecahan Masalah Dinamika Partikel Pada Mahasiswa Calon Guru Fisika Berdasarkan Taxonomy Of Introductory Physics Problems (TIPP). Jurnal Pendidikan Fisika Tadulako. 3 (4) 